\title{
DIGLOSIA
}

Terakreditasi Sinta 3 | Volume 3 | Nomor 2 | Tahun 2020| Halaman 163-178

P-ISSN 2615-725X | E-ISSN 2615-8655

http://diglosiaunmul.com/index.php/diglosia/article/view/38

\section{TUMPANG TINDIH KONFLIK PADA STRUKTUR NARATIF NOVEL LELAKI HARIMAU KARYA EKA KURNIAWAN}

\author{
Eka Kurniawan's “Lelaki Harimau”: \\ The Overlapping Conlicts in Narrative Structure
}

\author{
Emi Asmida \\ Magister Kajian Sastra dan Budaya \\ Fakultas Ilmu Budaya, Universitas Airlangga, Surabaya \\ Pos-el Korespondensi: emyasmida19@gmail.com
}

\begin{abstract}
This research aims to reveal the overlapping conflicts in Eka Kurniawan's Lekaki Harimau by applying Gerard Genette's narrative theory. Conflicts in this research were affected by narrative structure in this text, however, this research focused on analyzing dominant narrative elements found in this novel, such as order, frequency, focalization, and voice. Qualitative method is used in this research by applying in-depth reading (close reading) to expose any conflicts acquired in dominant narrative elements. The results of this study indicate that the central conflict in this story is a murder conflict which was carried out by others conflicts. This conflict originated from the overlapping conflicts experienced by the main character and the other member of his family, those are: (1) domestic violence, (2) emotional affection, and (3) batred conflict which involved acts of revenge. By discovering the finding from the analysis of overlapping conflicts, it revealed a criticism of the social condition in society about shaping the behavior of an individual which could be influenced by the smallest institutional system in the society called 'family'. In another sense, the family has an important role in forming attitudes and behavior toward each individual.
\end{abstract}

Keywords: narrative structure, order, perspective, voice, overlapping conflicts

\begin{abstract}
Abstrak: Penelitian ini bertujuan untuk mengungkap tumpang tindih konflik pada novel Lelaki Harimau karya Eka Kurniawan dengan memanfaatkan teori naratif Gerard Genette. Konflik pada novel dipengaruhi oleh struktur naratif dari teks tersebut sehingga tujuan penelitian ini akan difokuskan terhadap analisis unsur-unsur naratif dominan di dalam teks tersebut yang menyebabkan adanya konflik, seperti unsur tata, frekuensi, fokalisasi, dan tutur. Penelitian ini menggunakan metode kualitatif dengan menerapkan pembacaan mendalam (close reading) dengan memfokuskan membongkar konflik yang didapatkan dari unsur naratif yang dominan. Hasil penelitian ini menunjukkan adanya konflik sentral pada cerita tersebut yakni konflik pembunuhan yang disebabkan oleh konflik-konflik lainnya saling berkaitan. Konflik tersebut berasal dari tumpang tindih konflik yang dialami oleh tokoh utama dalam novel serta keluarganya. Adapun tumpang tindih konflik tersebut melibatkan (1) kekerasan rumah tangga, (2) konflik batin (kasih sayang keluarga, cinta tak terbalas), dan (3) konflik kebencian yang berujung balas dendam. Temuan dari hasil analisis struktur tersebut mengungkap sebuah kritikan terhadap kondisi sosial masyarakat dalam pembentukan perilaku suatu individu yang mana hal tersebut dapat dipengaruhi oleh sistem lembaga terkecil dalam masyarakat, yakni sebuah keluarga. Dalam arti lain, keluarga memiliki peranan penting dalam pembentukan sikap dan perilaku terhadap setiap individu.
\end{abstract}

Kata Kunci: struktur naratif, tata, pemandang, penutur, tumpang tindih konflik

\section{A. PENDAHULUAN}

Pada abad ke-21, karya sastra Indonesia memiliki beragam tulisan yang mengangkat berbagai tema menarik, mulai dari tema yang mencerminkan kehidupan sehari-hari suatu masyarakat atau bahkan hal-hal yang dianggap tabu serta terkesan mustahil untuk terjadi di lingkungan masyarakat. Namun, tak sedikit pengarang Indonesia yang menulis karya sastra dengan mengangkat tema permasalahan sosial atau konflik yang terjadi pada kehidupan sehari-hari masyarakat. Salah satunya ialah novel karya Eka Kurniawan yang berjudul Lelaki Harimau. Dalam menarasikan konflik yang terjadi pada 
beberapa tokoh di dalamnya, penyajian cerita novel Lelaki Hariman ini dikemas dengan teknik penceritaan yang menarik sehingga cukup rumit untuk dipahami.

Lelaki Harimau merupakan salah satu karya Eka Kurniawan yang memiliki keunikan tersendiri dari penyajian cerita pada setiap karya sastra yang telah dipublikasikan. Hal ini tidak menutup kemungkinan bahwa struktur teks yang terdapat pada karya sastra memunculkan masalah tersendiri, seperti halnya pada novel Lelaki Harimau yang diterbitkan pada tahun 2004. Novel Lekaki Harimau terbagi atas lima bab. Cerita pada novel tersebut dibuka dengan konflik utama yakni kematian yang sangat tragis menimpa tokoh Anwar Sadat. Kematian tersebut dikarenakan pembunuhan yang dilakukan oleh tokoh utama yang bernama Margio. Margio membunuhnya dengan cara menggigit leher Anwar Sadat hingga nyaris putus. Pembukaan cerita inilah yang disuguhkan dengan memaparkan peristiwa yang menjadi konflik utama yang hadir dikarenakan konflik-konflik pendukung lainnya. Konflik-konflik yang dihadirkan dalam penceritaan Lelaki Harimau sangat pelik sehingga antar konflik satu dengan yang lainnya bertumpang tindih membentuk suatu konflik yang kompleks. Sudjiman (1990) mendefinisikan konflik dalam sebuah novel sebagai sebuah bentuk perseteruan atau perselisihan yang muncul disebabkan adanya dua kekuatan yang saling bertentangan. Konflik tersebut dapat direpresentasikan oleh satu individu, dan masalah yang muncul dapat disebabkan oleh pertentangan individu tersebut dengan alam, masyarakat, tokoh lain dalam cerita, atau bahkan perlawanan terhadap diri tokoh itu sendiri.

Konflik-konflik saling tumpang tindih dalam novel tersebut disusun menggunakan teknik penceritaan yang cukup rumit yakni dengan menggunakan metode penceritaan episodik. Metode penceritaan episodik ini merupakan karakter dari tulisan Eka Kurniawan yang mana dengan menggunakan gaya penceritaan ini menghadirkan kisah dengan cara menampilkan tokoh tertentu sebagai tokoh utama pada satu bab dengan memfokuskan cerita berdasarkan pandangannya, kemudian pada bab selanjutnya bisa jadi tokoh sampingan yang mengambil alih pandangan tersebut. Akibatnya, terjadi pengulangan dalam penceritaan saat menceritakan atau mendeskripsikan peristiwa yang sama dan membuat novel tersebut seakan tengah diceritakan melalui sudut pandang beberapa orang (Furoidah, 2019).

Oleh karenanya, diperlukan untuk menata kejadian-kejadian dalam penceritaan pada teks Lelaki Hariman sehingga nantinya akan ditemukan kronologis dari konflik-konflik yang tumpang tindih tersebut. Untuk menganalisis tata kejadian pada penceritaan yang disebut juga sebagai sekuen, peneliti memanfaatkan teori naratif Gerard Genette. Selain mengungkap rangkaian (tata) penceritaan menjadi cerita yang kronologis, penelitian ini juga meneliti unsur-unsur naratif lainnya yang dominan dalam novel Lelaki Harimau.

Penelitian yang relevan, yaitu penelitian yang dilakukan oleh Agus Sardiansa (2018), dalam skripsinya peneliti memfokuskan penelitiannya pada keadaan psikologis para tokoh yang mengalami konflik. Penelitian tersebut sekilas serupa dengan penelitian ini karena persamaan konflik sebagai fenomena yang akan dibahas, akan tetapi, penelitian ini lebih menekankan pada analisis terhadap struktur naratif novel yang bermasalah yang dapat mana membentuk konflikkonflik tersebut sehingga peneliti tidak langsung memfokuskan penelitiannya terhadap konflik yang digambarkan oleh teks.

Berbeda dengan penelitian yang dilakukan oleh Wijayanti et al. (2018), dalam artikel jurnalnya, fenomena yang dipilihnya untuk dianalisis ialah dominasi 
laki-laki atas perempuan terhadap kehidupan seksualnya. Penelitian tersebut berbeda dengan penelitian ini karena perbedaan fenomena sebagai bahan utama untuk dikaji. Pada penelitian ini sendiri akan berfokus pada struktur naratif novel untuk dapat mengungkap tumpang tindih konflik yang dihadirkan melalui permasalahan struktur naratifnya. Selain mengurutkan kejadian atau peristiwa (tata) untuk menemukan motif dari adanya konflik-konflik yang ada, unsur-unsur naratif lainnya yang ditemukan dalam novel Lelaki Hariman ialah frekuensi, fokalisasi, dan tutur juga saling terkait untuk menguak konflik yang disajikan dalam novel Lelaki Harimau.

\section{B. METODE}

Penelitian ini menggunakan metode close reading, yakni dengan membaca sumber data yang berupa novel Lelaki Hariman berulang kali. Menurut Козак (2011), close reading merupakan teknik membaca yang membutuhkan ketelitian penuh terhadap teks dan kemampuan untuk memaknai konotasi yang ditulis oleh pengarang teks. Kemudian mencatat datadata yang dibutuhkan untuk mendukung dilakukannya analisis, serta menafsirkan atau menginterpretasi temuan-temuan berdasarkan data yang telah dianalisis dengan memanfaatkan teori naratif yang dikemukakan oleh Gerard Genette. Untuk teknik analisis data, peneliti memfokuskan untuk membongkar unsur-unsur naratif yang dominan pada teks novel Lelaki Harimau seperti tata, frekuensi, fokalisasi, dan tutur yang mendukung untuk mengungkap dibalik terjadinya konflik utama pada teks. Kemudian dari analisis tersebut, peneliti memaknai tindakantindakan tokoh sehingga menyebabkan terjadinya konflik pada teks tersebut sebagai kesimpulan dari penelitian ini.

\section{HASIL DAN PEMBAHASAN \\ 1. Tata (Order)}

Sebelum menginjak pembahasan lebih jauh mengenai analisis yang memanfaatkan aspek naratif pemikiran Genette, peneliti akan membatasi istilahistilah yang akan dipakai dalam penelitian ini. Dalam pembahasan naratologi, terdapat istilah "penceritaan" (sjuzet) dan "cerita" (fabula). "Penceritaan" merujuk pada urutan peristiwa yang disajikan dalam novel, atau bahan mentah cerita. Sedangkan "cerita" merupakan urutan peristiwa kronologis atau dalam kata lain "cerita" merupakan peristiwa yang disusun secara kronologis dari "penceritaan" berdasarkan waktu kejadiannya sehingga membentuk kisah yang berurutan.

Novel Lelaki Hariman merupakan cerita yang memiliki alur acak disebabkan adanya pola berulang dengan menghadirkan cerita di masa lalu yang dikisahkan oleh berbagai tokoh. Alur yang acak atau non-linear digambarkan pada cerita Lelaki Hariman tersebut menghadirkan pengisahan cerita yang tidak kronologis pula. Penceritaan dalam suatu teks sering kali membentuk alur yang non-linear disebabkan oleh waktu penceritaan yang tidak kronologis. Oleh karenanya, penceritaan dengan alur nonlinear jika diurutkan berdasarkan urutan waktu peristiwa atau kejadian maka akan bentuk sebuah cerita.

Novel Lelaki Harimau terbagi menjadi lima bab. Setiap bab terdapat beberapa sekuen ${ }^{1}$ peristiwa seperti yang tampak pada tabel berikut.
${ }^{1}$ Istilah sekuen mengacu pada satuan kisah, baik satuan peristiwa maupun bukan peristiwa. Pengenalan terhadap sekuen tergantung sepenuhnya pada pembaca. Sekuen harus terpusat pada kisah yang memiliki waktu, ruang, dan pokok gagasan yang sama, dikutip dari Tesis Bramantio (2008), Universitas Indonesia. 
Tabel 1. Pembagian Sekuen Novel Lelaki Harimau

\begin{tabular}{ll}
\hline Bab Lelaki Harimau & Sekuen Peristiwa \\
\hline Satu (halaman 1-38) & Sekuen 1-40 (40 Sekuen) \\
Dua (halaman 39-76) & Sekuen 41-64 (24 sekuen) \\
Tiga (halaman 77-114) & Sekuen 65-72 (8 sekuen) \\
Empat (halaman 115-152) & Sekuen 73-89 (17 sekuen) \\
Lima (halaman 153-190) & Sekuen 90-115 (26 sekuen) \\
\hline
\end{tabular}

Dari tabel tersebut dapat diketahui bahwa setiap bab dalam novel Lelaki Hariman terdiri atas beberapa sekuen dengan jumlah sekuen yang bervariasi. Sekuen peristiwa terbanyak terdapat pada Bab Satu di mana di dalam bab tersebut berisi konflik-konflik yang muncul di awal cerita sekaligus perkenalan tokoh-tokoh yang ada di novel tersebut beserta dengan peristiwa yang terjadi dan dilakukan pada tokoh-tokoh di dalamnya. Konflik yang muncul sebagai awal dari cerita yang juga merupakan konflik utama dalam teks Lelaki Hariman ialah kematian Anwar Sadat yang dibunuh oleh Margio. Pada bab selanjutnya, yakni Bab Dua, terdapat 24 sekuen yang mana di dalamnya berisi konflik-konflik pendukung dari konflik sentral. Konflik-konflik yang dimaksud ialah kekerasan rumah tangga yang Margio dapatkan dari ayahnya serta Margio ketahui hal itu menimpa Ibu dan adiknya, dan hal terebut menyebabkan kemarahan Margio yang menjadi-jadi sehingga ingin membunuh Komar, ayahnya. Selanjutnya, pada Bab Tiga berisi cerita masa muda Nuraeni dan Komar dari awal mula mereka dijodohkan hingga akhirnya berujung kekecewaan dan kemarahan yang Nuraeni rasakan terhadap Komar. Kemudian, Bab Empat dan Lima mengungkap peristiwa-peristiwa detail dari masa lalu Margio dan keluarganya yang juga merupakan cerita yang menyebabkan peristiwa-peristiwa pada bab sebelumnya terjadi.

Dalam pembagian sekuen-sekuen di atas, setiap bab dalam novel Lelaki Hariman disusun berdasarkan bentuk tekstual yang terdapat pada novel sehingga belum diketahui urutan ceritanya. Berikut adalah uraian dari sekuen-sekuen di atas berdasarkan penceritaannya.

1. Margio Membunuh Anwar Sadar

2. Kyai Jahro mengurus ikan-ikan di kolamnya

3. Mayor Sadrah lewat ketika Kyai Jahro memberi pakan ikan-ikannya

4. Mayor Sadrah berbincang dengan Kyai Jahro

5. Ma Soma datang menghampiri Kyai Jahro yang sedang bersama dengan Mayor Sadrah untuk memberi tahu bahwa Anwar Sadat meninggal dibunuh Margio

6. Siang hari sebelum kejadian tersebut, Mayor Sadrah melihat Margio menenteng samurai bangka berkarat

7. Sore harinya, Mayor Sadrah menyuruh anak-anak kampung (termasuk Margio) untuk beristirahat untuk persiapan memburu keesokan paginya

8. Ingatan Mayor Sadrah akan pemburuannya bersama anak-anak di tahun-tahun terakhir

9. Mayor Sadrah mendengar Margio minggat dari rumahnya beberapa minggu ke belakang

10. Mayor Sadrah dan anak-anak melalukan pemburuan

11. Komar bin Syueb meninggal (ayah Margio)

12. Margio kembali pulang ke rumahnya

13. Margio datang ke rumah Mayor Sadrah selepas pemakaman ayahnya

14. Deskripsi pikiran Mayor Sadrah tentang hubungan Margio dan ayahnya, sifat Margio

15. Mayor Sadrah pergi berkeliling kota dan bertemu dengan Kyai Jahro disusul oleh Ma soma yang datang 
16. Polisi datang di rumah Anwar Sadat

17. Anwar Sadat datang ke kampung menjual lukisan seni di pinggir pantai

18. Anwar Sadat kawin dengan gadis calon bidan

19. Anwar Sadat datang ke warung Serabi pagi hari (saat sebelum ia dibunuh)

20. Maharani tidak mau berbicara dengan siapa pun (malam hari)

21. Maharani kembali ke pondokan (pagi hari)

22. Anwar Sadat sarapan di warung serabi

23. Maharani mengurung diri di kamarnya

24. Kasia, Laila, Maesa Dewi, dan para tetangga berduka atas kepergian Anwar Sadat

25. Ma Soma menemukan Anwar Sadat

26. Kyai Jahro dan Mayor Sadrah datang ke rumah duka Anwar Sadat

27. Kyai Jahro menyuruh orang-orang untuk persiapan pemakaman Anwar Sadat

28. Margio bersama kawan-kawannya di lapangan bola sepuluh menit sebelum kematian Anwar Sadat

29. Laila berbincang dengan Margio

30. Margio mengajak Agung Yuda ke warung

31. Margio berpamitan ke Agung Yuda untuk pergi ke rumah Anwar Sadat

32. Anwar Sadat memberi makan kalkun

33. Ma Soma menyapu halaman Surau

34. Anwar Sadat bertemu Margio

35. Margio mengakui membunuh Anwar Sadat kepada Polisi

36. Maesa Dewi pingsan melihat ayahnya tergeletak di lantai penuh darah

37. Ma Soma melihat Margio dengan tangan berlepotan darah dan mendatangi rumah Anwar Sadat melihat jejak darah dari tubuh Margio

38. Orang-orang menghampiri Margio yang wajahnya berlumur darah

39. Margio dibawa Joni Simbolon ke rayon militer

40. Mayor Sadrah mengunjungi Margio selepas salat jenazah
41. Mameh melihat harimau keluar dari tubuh Margio

42. Margio menemukan harimau di dalam dirinya pada pagi hari berminggu lalu sebelum minggat

43. Perjalanan Margio menuju rumah kakeknya dan mendengar cerita dari Ma Muah tentang harimau yang ada pada diri orang-orang di kampung tersebut

44. Margio mendapat wasiat dari kakeknya bahwa harimau itu akan diwariskannya kepada keturunannya

45. Margio mendapatkan harimaunya

46. Margio berkata kepada Mameh ingin membunuh ayahnya (malam sebelum mendapatkan harimau)

47. Margio melihat pertunjukan sirkus

48. Margio tidur di surau malam hari

49. Niat Margio membunuh ayahnya bertahun-tahun

50. Margio sedih melihat ibunya kehilangan anak ketiganya

51. Komar meninggalkan rumah, tidak peduli dengan bayi kecil di rumahnya

52. Margio menggelar selamatan kecil untuk adiknya, Marian

53. Komar kembali ke rumah setelah pemakaman Marian

54. Komar membuat selamatan tujuh hari meninggalnya Marian

55. Margio pergi dari rumah

56. Margio kembali ke rumah selepas acara selamatan usai

57. Margio minggat dari rumah

58. Komar sekarat

59. Mameh mengurus Komar

60. Komar meninggal

61. Deskripsi pikiran Mameh: ibunya sedih mendengar kabar Komar meninggal, ingatan ibunya disetubuhi Komar dengan ganas, Komar melihat Mameh di kamar mandi, kesenangan mengetahui Komar meninggal

62. Margio pulang

63. Komar dimakamkan

64. Mameh menyuruh ibunya kawin lagi

65. Keluarga Margio pindah ke 131 
66. Nuraeni diberitahu akan menikah dengan Komar bin Syueb

67. Nuraeni berkencan dengan Komar

68. Komar pergi merantau

69. Kesedihan dan kekecewaan Nuraeni tidak menerima surat dari Komar

70. Komar menikahi Nuraeni

71. Margio dan Mameh lahir

72. Nuraeni meluapkan kemarahannya kepada peralatan memasak di rumah 131

73. Ingatan Margio: kekerasan yang diperoleh ibunya dari Komar, pukulan yang diterima Margio dan Mameh dari Komar

74. Komar membeli tanah rumahnya

75. Komar dan Margio merenovasi rumah

76. Nuraeni menanam berbagi macam tanaman

77. Nuraeni hamil anak ketiga

78. Nuraeni bekerja di rumah Kasia, istri Anwar Sadat

79. Margio menonton TV di rumah Anwar Sadat sehabis isya

80. Margio pergi bersama Maharani membeli lauk

81. Nuraeni bahagia bekerja di rumah Kasia dan Anwar Sadat

82. Komar mengamuk mengetahui kehamilan Nuraeni

83. Margio pergi ke pos ronda

84. Komar bersedih

85. Deskripsi kenangan Komar: merantau untuk bekerja, perkawinan dengan Nuraeni, menyadari kekesalan Nuraeni tidak dikirimi surat cinta ketika ia merantau

86. Pembicaraan Nuraeni, Mameh dan Margio tentang anak yang dikandungnya untuk balas dendam kepada Komar

87. Margio tidur di pos ronda

88. Margio memanggil Kasia

89. Nuraeni melahirkan anak ketiga

90. Margio berkencan dengan Maharani

91. Maharani pulang sehari setelah kematian Komar

92. Margio ikut rombongan sirkus
93. Margio kembali pulang

94. Margio memakamkan Komar

95. Mameh berbagi cerita kepada Margio

96. Marian sekarat

97. Margio mencari Komar

98. Komar pulang ke rumah

99. Komar pergi ke kios cukurnya

100. Komar menghilang di hari ketujuh kelahiran Marian

101. Mameh menyuruh Margio memotong ayam untuk acara selamatan Marian

102. Nuraeni memberi nama anaknya "Marian"

103. Marian meninggal

104. Margio bersama Maharani di pemutaran film

105. Margio mendatangi rumah Anwar Sadat

106. Margio mabuk di pos ronda

107. Nuraeni bersedih atas kematian Marian

108. Margio berbincang dengan Maharani

109. Maharani pergi meninggalkan Margio

110. Margio pulang ke rumahnya dan tidak dapat tidur hingga pagi

111. Margio berjalan di gang-gang perkampungan

112. Margio pergi ke pos ronda

113. Margio pergi ke lapangan bola

114. Margio pergi ke warung Agus Sofyan

115. Margio ke rumah Anwar Sadat dan membunuh Anwar Sadat 

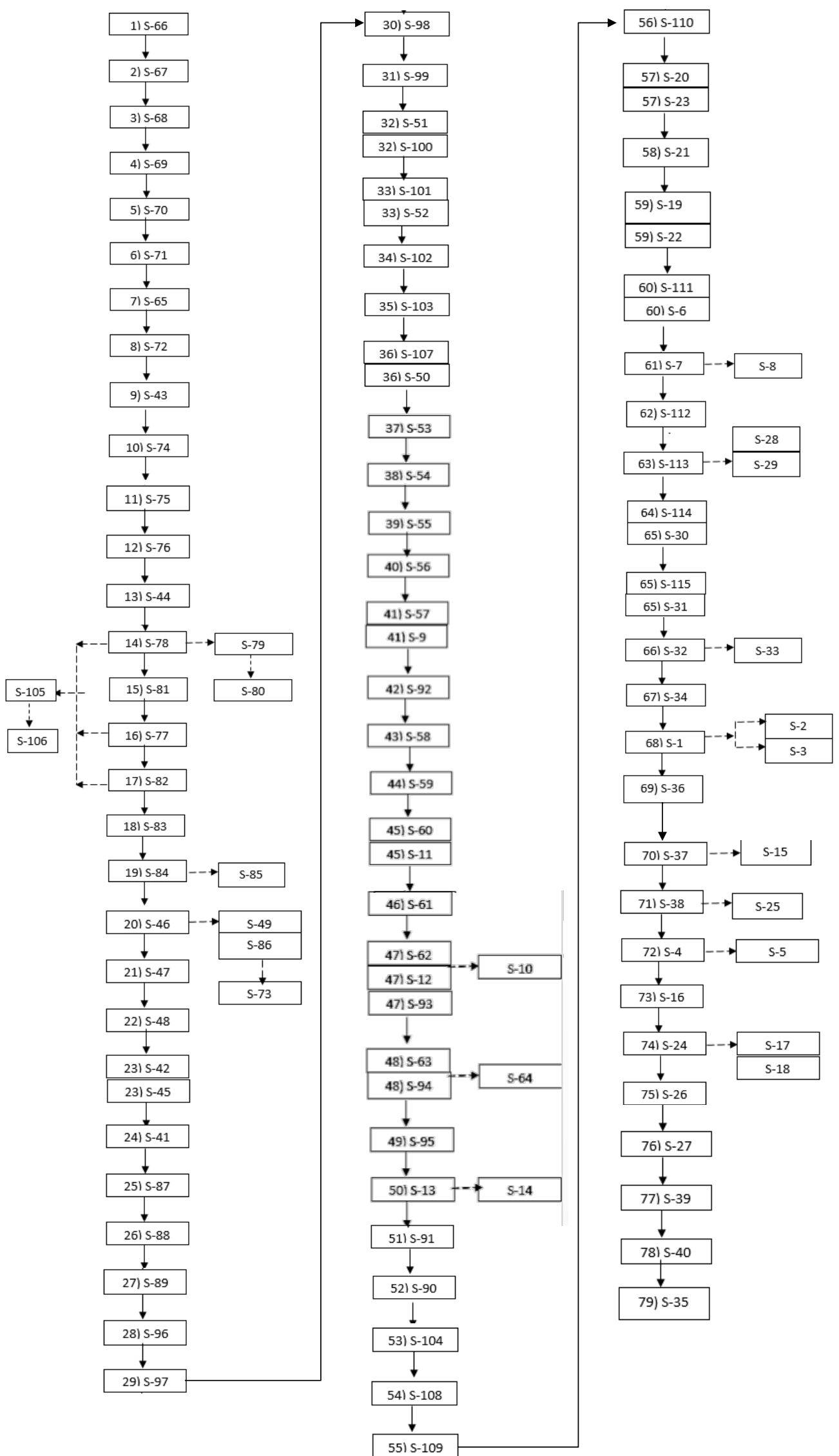

Gambar 1. Bagan Kronologis 
Data sekuen di atas merupakan sekuen peristiwa yang dinarasikan secara tekstual dalam novel Lelaki Harimau, akan tetapi urutan peristiwa tersebut tidak kronologis. Hal ini dikarenakan terdapat peristiwa-peristiwa lain yang terjadi sebelum peristiwa pada sekuen 1 terjadi. Sekuen-sekuen lainnya dapat dikatakan sebagai proses peristiwa yang mengantarkan terjadinya peristiwa pada sekuen 1 (S-1). S-1 merupakan sebuah konflik sentral dalam novel Lelaki Hariman tetapi bukan merupakan sebuah awal dari cerita. Hal ini dikarenakan terdapat peristiwa-peristiwa lain yang mendukung tokoh Margio melakukan pembunuhan kepada Anwar Sadat namun dinarasikan di bab selanjutnya. Untuk itu diperlukan untuk mengurutkan peristiwa-peristiwa atau sekuen-sekuen di atas secara kronologis.

Pada bagan kronologis, terdapat garis panah putus-putus. Garis ini menunjukkan sekuen peristiwa yang terjadi pada tokoh lain yang dilakukan pada saat yang bersamaan. Sekuen yang bergabung pada satu bagan merupakan suatu sekuen peristiwa yang sama namun dinarasikan berkali-kali pada bab lain. Pikiran tokoh atau deskripsi pikiran tokoh juga berada pada garis panah putus-putus karena merupakan satu sekuen yang dilakukan pada dilakukan pada satu waktu meski berbeda gagasan.

Melalui bagan kronologis, dapat diketahui bahwa awal mula cerita yang menyebabkan konflik utama terjadi ialah Sekuen 66 (S-66) di mana merupakan kisah asmara Komar dan Nuraeni. Kisah mereka dimulai dari perjodohan yang awal mulanya membuat Nuraeni sangat mencintai Komar. Namun seiring dengan berjalannya waktu, Komar menunjukkan sifat bengisnya yang melibatkan tindakan eksploitasi seksual berupa kekerasan seksual.

Permusuhan itu mulai datang sejak malam pertama, kala Nuraeni telah teronggok di tempat tidur kelelahan, [...]. Komar yang keburu nafsu mengajaknya telanjang dan bercinta, tapi Nuraeni hanya menggeram tanpa mengubah rengkuhan. Tanpa banyak tanya Komar melucuti pakaiannya sendiri [...] tanpa memedulikan baju kebayanya, Komar segera menerjang dan jatuh di atasnya, menarik turun celana dalam Nuraeni, lalu celana dalamnya sendiri, kemudian menusuknya. Mereka bercinta tanpa katakata, hingga pegal dan jatuh tertidur [...] masa-masa bercinta selalu merupakan saat yang sulit bagi mereka, sebab Nuraeni selalu menampilkan keengganan tertentu dan Komar hampir memaksanya jika nafsu telah naik ke tenggorokan, dan kerap kali itu hampir serupa pemerkosaan bengis (Kurniawan, 2016, hal. 110-111).

Kutipan di atas menunjukkan hubungan seksual yang mengerikan namun Nuraeni tidak dapat berbuat apaapa bahkan tidak untuk melawan. Cerita yang demikian menimbulkan konflik batin bagi Nuraeni. Konflik batin (Neurosis) merupakan permasalahan yang disebabkan adanya keinginan atau gagasan yang bertentangan dengan keinginan diri sehingga mempengaruhi perilaku penderitanya (Surakhmad, 1980 dalam Retnaningsih, 2010, hal. 17). Sebagai akibat dari konflik batin yang dialaminya, ia menghabiskan banyak waktunya dengan kesedihan dan kemurungan. Pada umumnya, penyebab seseorang mengalami konflik batin ialah seorang tersebut tidak dapat mencari solusi atau jalan keluar atas permasalahan yang dihadapinya sehingga ia memilih untuk diam dan memendamnya. Serupa dengan Nuraeni, ketidakmampuannya dalam menangani permasalahannya, Nuraeni hanya dapat melampiaskan kemarahannya dengan berbicara lantang dan penuh kemarahan kepada peralatan memasak di dapur hingga anggota keluarganya mengira bahwa Nuraeni mengalami gangguan jiwa. Hal ini juga merupakan dampak dari konflik batin yang dialaminya yang dapat menyebabkan gangguan kesehatan mental dan gejalanya dapat ditunjukkan dengan gejala susah berinteraksi, stres 
berkepanjangan, mudah putus asa dan kecewa.

Alih-alih mencari solusi atas permasalahan yang dialaminya, Nuraeni memilih melakukan hal yang mana menciptakan konflik baru. Ia mencari kebahagiaan baru dengan berhubungan seksual dengan majikannya, Anwar Sadat, seperti yang terlihat pada (S-105). Hanya Margio, anak dari Nuraeni, yang memahami alasan dari kemurkaan Komar karena Margio mengetahui perselingkuhan yang dilakukan oleh Ibunya dengan Anwar Sadat.

\footnotetext{
"Demi senyum keparat itu, kuampuni dirimu tidur dengan bangsat mana pun." Hampir gila ia memikirkan semua seangkrut keluarganya, sebelum dengan satu kesaran yang aneh, ia memutuskan untuk berpihak pada ibunya, demi mempertahankan roman riang di wajahnya (Kurniawan, 2016, hal. 184).
}

Dalam hal ini, Margio memiliki konflik batin yang sama dengan Nureani. Ia telah mengetahui siapa yang bersalah, namun dirinya tidak dapat melakukan tindakan apa pun. Menurut Globe (1971), setiap individu memiliki potensi yang cukup besar atas konflik batin antara dorongan dan kontrol, antara hasrat tuntutan masyarakat dan hasrat pribadi (Retnaningsih, 2011). Konflik batin yang dialami oleh Margio dapat ia kontrol karena ia memikirkan kebahagiaan yang terpancar dari wajah Ibunya baik ketika berhubungan dengan Anwar Sadat, serta ketika menimang bayi dari hasil hubungannya dengan lelaki tersebut. Tindakan Margio dalam mengontrol gejolak amarahnya terhadap Anwar Sadat dan Ibunya dapat digolongkan dalam kategori perilaku abdikrat (abdicrat behaviour) yang menurut Schutz didefinisikan sebagai tindakan perilaku sosial dalam menghindari pembuatan keputusan karena merasa tidak mampu dalam mengambil keputusan (Rokhmansyah, 2018, hal. 31). Ketidakmampuan dalam mengambil keputusan ini dikarenakan Margio tidak memiliki kekuasaan apa pun. Dirinya hanya seorang anak yang mana dalam dogma masyarakat tidak memperbolehkannya untuk melawan orang tua, terlebih Anwar Sadat memiliki kekuasaan berupa materi sehingga dapat dikatakan ia adalah seorang yang disegani dalam lingkungannya. Hal ini menambah keraguan dalam diri Margio untuk melakukan perlawanan terhadap hal yang tidak disukainya.

Tidak berhenti di situ, kebahagiaan Nuraeni kembali direnggut ketika bayi yang dilahirkannya meninggal dalam usianya yang baru menginjak tujuh hari, lalu kemudian disusul oleh kematian Komar, peristiwa-peristiwa tersebut menimbulkan konflik baru bagi Nureani. Kemudian Margio meminta Anwar Sadat untuk menikahi Nureani untuk mengembalikan kebahagiaannya. Namun Margio hanya mendapatkan tolakan dari Anwar Sadat dengan menyatakan bahwa dirinya tidak mencintai Nuraeni. Mendengar pertanyaan Anwar Sadat, kemarahan yang telah lama ia tahan sejak ia mendapati tubuh ibunya menyatu dengan Anwar Sadat, maka Margio tidak tahan lagi untuk menahannya. Kala itu, harimaunya keluar dan menyebabkan terjadinya pembunuhan seperti yang terlihat pada sekuen 1 .

Pembunuhan yang terjadi terhadap Anwar Sadat dapat dikatakan sebagai dampak atas konflik batin yang selama ini tidak terselesaikan baik oleh Nuraeni, maupun Margio. Margio menjadi satusatunya tokoh yang sempat menahan untuk melakukan tindakan balas dendam terhadap Anwar Sadat karena konflikkonflik lainnya yang mendukung tindakan Margio untuk tidak lagi menahannya dengan cara membunuh Anwar Sadar. Konflik batin yang diperlihatkan dalam penceritaan Lelaki Harimau ini dapat berdampak buruk bagi tingkah laku dan kepribadian individu yang mana dapat 
merugikan diri sendiri dan pihak lain yang terlibat.

Dengan mengungkap cerita, maka akan diperoleh urutan kejadian atau peristiwa yang kronologis yakni dimulai dengan masa muda tokoh Komar bin Syueb dan juga Nuraeni hingga pembunuhan Anwar Sadat yang dilakukan oleh Margio. Dari analisis penceritaan menjadi sebuah cerita di atas, diperoleh unsur tata atau order yang merupakan hubungan antara penceritaan dan cerita dalam novel Lelaki Harimau. Sebagaimana tata yang ditemukan pada analisis di atas bahwa terdapat perbedaan tata waktu penceritaan dan tata waktu cerita, perbedaan waktu antara penceritaan dan cerita ini disebut anakronis (anachronies) (Genette, 1980). Terdapat dua kemungkinan yang dapat menyebabkan sebuah naratif menjadi anakronis terhadap cerita, yakni analepsis dan prolepsis. Analepsis merupakan sekuen peristiwa yang seharusnya terjadi lebih awal tetapi dimunculkan kemudian. Sedangkan prolepsis ialah sekuen peristiwa yang terjadi kemudian tetapi dimunculkan lebih awal. Sementara itu, bentuk anakronis dalam novel Lelaki Hariman dapat diklasifikasikan dalam tipe prolepsis di mana peristiwa-peristiwa yang terjadi di masa lampau dimunculkan kembali ke dalam cerita masa kini sebagai akibat dari peristiwa yang terjadi pada masa kini. Pada setiap peristiwa yang diceritakan selalu ada peristiwa lampau yang diceritakan kembali sehingga sekuen-sekuen ini muncul dikarenakan adanya sekuen lain di masa lalu, baik itu muncul melalui ingatan ataupun lamunan, dan selalu diceritakan demikian. Keberulangan pola yang mengungkap sekuen di masa lampu, lalu kemudian cerita akan kembali dilanjutkan ke masa kini membuktikan bahwa bentuk anakronis pada novel ini ialah prolepsis atau flash-forward.

Selanjutnya, melalui analisis alur nonlinear dengan mengurutkan cerita secara kronologis, ditemukan bahwa penceritaan, cerita, tata (order), serta anakronis prolepsis saling berkaitan untuk membuktikan adanya sebuah penekanan pada cerita masa lalu yang menjadi konflik sehingga memunculkan konflik yang lebih besar pada masa kini yang merupakan sentral cerita. Sentral cerita pada cerita Lelaki Harimau adalah ketika Margio membunuh Anwar Sadat dengan cara menggigit lehernya hingga hampir putus (sekuen 1). Pada sekuen 1 yang merupakan sentral cerita ataupun konflik utama didukung oleh konflik-konflik lainnya yang terjadi di masa lalu, yakni ketika Anwar Sadat tidak ingin menikahi Ibu Margio yang telah melahirkan anak dari Anwar Sadat (subsekuen dari Sekuen 105). Selain itu, konflik yang mendukung lainnya ialah pertentangan pada diri Margio yang tidak tega melihat ibunya bersedih karena masa lalunya bersama suaminya Komar bin Syueb (Sekuen 61, 72, 82) serta kesedihannya yang menjadi-jadi setelah anak ketiganya yang merupakan hasil hubungannya dengan Anwar Sadat meninggal (sekuen 103). Konflik-konflik pendukung konflik sentral juga dikarenakan bentuk kekecewaan Margio terhadap sosok Ayah ataupun Suami yang tidak bisa membuat bahagia Istri dan anakanaknya. Sekuen-sekuen yang menjadi konflik sentral ataupun pendukung merupakan sebuah pengulangan dari sekuen-sekuen yang terjadi di masa lalu dan juga masa kini. Untuk membahas pengulangan yang terdapat pada cerita, akan dijelaskan pada sub-bab analisis frekuensi.

\section{Frekuensi}

Di dalam naratif, terdapat peristiwaperistiwa identik atau identical events. Namun, meskipun identik, peristiwaperistiwa tersebut memiliki kemungkinan muncul dengan cara yang berbeda di dalam naratif. Frekuensi membahas ditampilkannya perulangan pada suatu peristiwa dalam cerita dengan perulangan penceritaan di dalam teks, atau keseringan 
muncul tidaknya suatu peristiwa dalam teks (Hartono, 2005).

Terdapat empat jenis relasi frekuensi yang muncul dalam naratif: (1) Frekuensi singular, wacana tunggal yang dinarasikan satu kali, terjadi satu kali; (2) frekuensi multipel-singular, beberapa kali wacana untuk menceritakan beberapa kali peristiwa; (3) frekuensi repetitif, merupakan beberapa kali wacana untuk peristiwa yang sama; (4) frekuensi iteratif, merupakan satu wacana untuk beberapa momen cerita (Genette dalam Chatman, 1980, hal. 78-79).

Pada teks Lelaki Harimau, terdapat peristiwa-peristiwa identik baik terjadi satu kali atau lebih, tetapi selalu dinarasikan beberapa kali. Pengulangan-pengulangan tersebut meliputi kekerasan rumah tangga, kasih sayang, dan pembunuhan. Ketiga pola tersebut merupakan konflik-konflik yang terdapat di dalam teks Lelaki Hariman dan merupakan pola yang saling berkaitan. Pengulangan atau frekuensi atas tiga pola tersebut akan dijabarkan di bawah ini.

\section{a. Kekerasan dalam Rumah Tangga}

Setelah menganalisis urutan atau order dari penceritaan Lelaki Harimau sehingga didapatkan urutan cerita yang kronologis, kemudian dapat diketahui bahwa yang menyebabkan terjadinya konflik sentral yang menimpa Anwar Sadat karena dibunuh oleh Margio adalah kekerasan rumah tangga yang dialami oleh Nuraeni. Hal ini dialami Nuraeni sehingga mencari kesenangan dengan lelaki lain dan membuat Margio murka. Kekerasan yang terjadi pada rumah tangga Komar dan Nuraeni dinarasikan berulang kali dan terjadi pada waktu yang berbeda. Berikut ini adalah kutipan-kutipan yang menunjukkan kekerasan rumah tangga dalam teks Lelaki Harimau.

Ia juga mengenal ayahnya, yang telah sering melihatnya bagaimana lelaki bengis itu memukul bocah itu untuk kejahilan-kejahilan sepele (Kurniawan, 2016, hal. 9).
Betapa mengejutkan itu bagi Mameh, menyadari perempuan ini bisa bersedih pada suami yang sepanjang hidupnya dihabiskan untuk memukuli dirinya, untuk salah ini salah itu dan tanpa salah sekalipun (Kurniawan, 2016, hal. 67-68).

Ada kalanya untuk mengulangi keengganan Nuraeni yang makin menjadi-jadi, Komar mesti memukulnya, menampar pipinya bukanlah hal yang jarang, malahan sering pula menempeleng betis indahnya dengan kaki ganasnya, membuat roboh dan tak berdaya, dan saat tak ada tenaga itulah Komar bisa merampok sekelangkangnya (Kurniawan, 2016, hal. 111-112).

Sepanjang hidupnya, ia telah sering melihat Komar memukul Nuraeni di depan matanya sendiri, menghajarnya hingga babak belur. Margio terlampau kecil untuk melerai, dan ia sendiri sering mendapatkan bagiannya pula (Kurniawan, 2016, hal. 115).

Kadang-kadang itu dilakukan pula di depan orang, hingga Nuraeni mesti berlari mengelilingi rumah dan Komar mengejarnya, dan di antara mereka iblis-iblis terbang menyulut marah hingga Nuraeni masuk ke rumah mencoba membentengi diri dengan pintu namun Komar selalu berhasil mendobraknya [...] Nuraeni akan tertangkap dalam dekapan, dibantingnya ke lantai, dan ditendang pahanya berkali-kali (Kurniawan, 2016, hal. 115-116).

Bocah lain telah berlarian pulang tapi tidak Margio, sebab sepanjang sore Komar habis memukuli Nuraeni dan Margio enggan melihat itu berlanjut sampai hari gelap serta berniat menghabiskan malam melihat televisi di sana dan melewatkan siangnya berbaring di surau (Kurniawan, 2016, hal. 127).

[...] gempa amukan itu datang sejadi-jadinya, mengejutkan Margio dan Mameh sekaligus, sebab telah lama Komar demikian abai pada istrinya, meski masih kerap memukulinya. Kini amuk itu datang lebih ganas, seperti amarah yang tertahan, menyeret perempuan itu dari dapur ke tengah rumah, dan menempelengnya tanpa mengatakan apa pun. Nuraeni menjerit, kini tampaknya perempuan itu hendak melawan, barangkali mempertahankan gumpalan cinta di rahimnya (Kurniawan, 2016, hal. 143).

"Ayahmu Anwar Sadat meniduri ibuku Nuraeni, dan lahirlah gadis kecil yang mati di 
hari ketujuh bernama Marian, sebab ayahku mengetahui dan memukuli ibuku hingga Marian lahir dan bahkan telah sekarat" (Kurniawan, 2016, hal. 186).

Kutipan di atas yang merujuk pada kekerasan dalam rumah tangga Nuraeni dan Komar maupun yang Komar lakukan kepada Margio merupakan jenis relasi frekuensi repetitif. Disebut demikian karena peristiwa-peristiwa kekerasan dalam rumah tangga merupakan suatu jenis peristiwa yang sama namun dinarasikan beberapa kali dalam teks. Pengulangan peristiwa kekerasan dalam rumah tangga Komar dan Nuraeni menunjukkan bahwa pentingnya sebuah kerukunan dan kedamaian dalam keluarga untuk sebuah ketenangan jiwa masingmasing anggota keluarga. Dengan adanya konflik kekerasan rumah tangga seperti yang tergambar dalam teks Lelaki Harimau, dapat menyebabkan konflik-konflik lainnya yang lebih besar terjadi pada salah satu atau semua anggota keluarga. Seperti yang terjadi pada Margio, ia telah lama menahan amarahnya untuk tidak melawan kekerasan yang dilakukan ayahnya dan juga tidak melakukan tindakan apa pun ketika mengetahui ibunya mencari kesenangan lain di luar rumahnya dengan bercinta bersama orang lain.

\section{b. Kasih Sayang (Konflik Batin)}

Selain kekerasan dalam rumah tangga yang dominan pengulangannya dalam teks Lelaki Harimau, terdapat pula kasih sayang yang menjadi kontradiksi dari kekerasan rumah tangga. Meskipun peristiwa yang dominan adalah kekerasan dalam rumah tangga, namun terdapat kasih sayang yang juga merupakan sebuah peristiwa penting sehingga berpengaruh terhadap peristiwa lainnya. Berikut adalah narasi terkait dengan pengulangan atau frekuensi yang mencerminkan kasih sayang.

Semua orang tahu ayahnya kasar minta ampun, terutama pada ibunya, dan betapa Margio mengasihani ibunya, namun Margio sangatlah pengalah pada semua polah si ayah, sebagaimana ia menjadi penengah cekcok antarteman (Kurniawan, 2016, hal. 25-26).

Margio sendiri tak pernah bisa melacak dari mana asal-usul kemarahannya atas Komar bin Syueb. Baginya itu serupa piutang yang mesti ditagihnya, yang telah menumpuk sehingga hampir membikin dirinya sendiri bangkrut secara mental. Rasa cinta yang tak kepalang kepada ibu dan adiknyalah, barangkali, yang telah menahannya dari kemarahan yang memaharaja (Kurniawan, 2016, hal. 54).

"Demi senyum keparat itu, kuampuni dirimu tidur dengan bangsat mana pun." Hampir gila ia memikirkan semua seangkrut keluarganya, sebelum dengan satu kesaran yang aneh, ia memutuskan untuk berpihak pada ibunya, demi mempertahankan roman riang di wajahnya (Kurniawan, 2016, hal. 184).

Jenis relasi frekuensi adalah frekuensi multipel-singular di mana terdapat dua penceritaan yang menunjukkan kasih sayang kepada ibu dan adiknya atau bahkan kepada Komar yang dinarasikan lebih dari dua kali. Dengan adanya wacana ini menyebabkan peristiwa-peristiwa lainnya terjadi, seperti kemarahan Margio yang berhasil ditahannya untuk tidak membunuh Komar yang telah lama ingin ia lakukan. Meskipun Margio tahu pasti bahwa Ibunya bersalah dengan tidur bersama Anwar Sadat, saat itu ia tetap mengampuni ibunya dan juga Anwar Sadat demi melihat kebahagiaan yang tidak pernah ibunya dapatkan dari keluarganya sendiri. Pengulangan narasi kasih sayang pada teks ini menunjukkan bahwa pentingnya kasih sayang untuk meredam amarah sebesar apa pun yang dimiliki oleh tokoh. Frekuensi ini tentunya berhubungan dengan frekuensi lainnya (balas dendam dan juga kekerasan rumah tangga) karena dengan adanya kasih sayang atau rasa cinta yang dimiliki seseorang kepada orang lain, maka ia akan berhati-hati untuk bertindak dengan tujuan membuat orang yang ia sayangi tetap bahagia atau bahkan tidak menjadi semakin bersedih karena tindakan yang dilakukannya. Pengulangan narasi kasih sayang ini juga dapat dikatakan sebagai 
penawar dari konflik-konflik yang menegangkan yang dialami oleh Margio.

\section{c. Balas Dendam}

Pengulangan lainnya yang terdapat pada teks Lekaki Hariman adalah peristiwa balas dendam yang dilakukan oleh Margio. Berikut adalah kutipan yang menunjukkan pengulangan terkait dengan balas dendam.

"aku takut kali ini sungguh-sungguh kubunuh seseorang". Beberapa waktu sebelum minggat, Agung Yuda telah mendengar Margio berniat membunuh ayahnya. Ia mengaku tubuhnya ada isi, dan sanggup membunuh tanpa ragu (Kurniawan, 2016, hal. 25).

Seperti kemudian menjadi pengakuannya kepada polisi, ia memang membunuh membunuhnya dengan cara menggigit putus urat lehernya (Kurniawan, 2016, hal. 31).

Malam sebelum Margio berjumpa dengan harimaunya, untuk pertama kali ia bilang kepada Mameh ingin membunuh ayah mereka. Mameh pernah mendengar itu dari seseorang, sebab Margio berkali-kali memaki di pos ronda dan kata -kata yang keluar adalah semacam itu, bahwa jika sempat ingin dibunuhnya Komar bin Syueb, tapi hal itu tak pernah terjadi dan tak ada tanda-tanda akan terjadi (Kurniawan, 2016, hal. 49).

Sekaligus kematian ini menambah-nambah minyak bagi api kebencian Margio pada ayahnya hingga ia berpikir, jika selama ini dirinya ingin membunuh Komar bin Syueb, inilah saatnya (Kurniawan, 2016, hal. 56).

[...] Mameh bisa lihat matanya yang bertambah-tambah kemilau dan tambahtambah pijar kuning. Masih diingat kehendak Margio untuk membunuh Komar, dan kehendak itu makin menjadi-jadi tanpa mesti mengatakannya [...] Margio bilang pada Mameh, "aku akan pergi." Dan menambahkan, "jika tidak, aku akan membunuh lelaki ini”" (Kurniawan, 2016, hal. 61).

Kepada kedua anak itu, ia berkata pelan: "jika ia lahir, ia akan datang membalas dendam membunuh Komar bin Syueb." Mameh hanya menangis menanggapinya, sementara Margio semakin menemukan kristal-kristal hasrat membunuh ayahnya (Kurniawan, 2016, hal. 147-148).

Mereka terlalu mengenal baik si bocah Margio maupun si tua Anwar Sadat, dua makhluk itu yang takkan terpikirkan ambil bagian dari suatu drama tragis semacam itu, tak peduli senafsu apa pun Margio ingin membunuh seseorang, dan semenyebalkan apa pun lelaki yang bernama Anwar Sadat (Kurniawan, 2016, hal. 4).

Seperti yang telah disebutkan dianalisis tata atau order bahwa pembunuhan yang menimpa Anwar Sadat merupakan konflik sentral dalam teks Lelaki Harimau. Hal ini tentu tidak terjadi begitu saja dikarenakan terdapat faktorfaktor lain yang menyebabkan Margio melakukan hal sedemikian. Adalah hasrat balas dendam yang menyelimuti pikirannya jauh sebelum ia berniat untuk mengakhiri hidup Anwar Sadat, ia telah memiliki keinginan yang menggebu-gebu untuk membunuh ayahnya, Komar bin Syueb. Hal ini sebabkan oleh rasa bencinya karena Komar telah membuat ibunya tidak bahagia karena kekerasan yang selalu diberikannya kepada Nuraeni. Niat untuk membalas dendam tidak pernah terlaksana karena kasih sayangnya yang terlanjur memuncak kepada ibu dan adiknya sehingga dapat menahan dirinya untuk tidak membalas dendam kepada Komar. Selain itu, dikarenakan Komar telah meninggal tanpa membuat tangan Margio kotor untuk membunuhnya. Tetapi dendamnya tidak kuasa lagi ia tahan ketika ia mengetahui bahwa Anwar Sadat tidak mau bertanggung kepada Nuraeni. Kemarahan yang selama ia tahan baik kepada Komar yang sering melakukan kekerasan kepada ibunya dan Anwar Sadat yang meniduri ibunya, semakin menjadijadi ketika Anwar Sadat menolak permintaannya untuk menikahi ibunya supaya ia bisa kembali bahagia seperti kala mereka bercinta dan kebahagiaan selama mengandung Marian yang merupakan hasil dari hubungan ibunya dengan Anwar Sadat. 
Dari pengulangan-pengulangan peristiwa identik di atas, dapat diketahui bahwa frekuensi yang dimunculkan ialah konflik-konflik yang berasal dari keluarga tokoh utama. Dari semua konflik yang ada, dapat dikatakan bahwa penulis ingin menekankan bahwa permasalahan besar yang terjadi di luar, dapat berasal dari lingkup kecil lingkungan kita tinggal, yakni adalah keluarga. Konflik sekecil apa pun dalam keluarga akan mempengaruhi tingkah laku anggota di dalamnya. Hal ini dikarenakan keluarga merupakan sebuah lembaga sosial paling dasar dari semua lembaga lainnya yang ada di dunia. Umumnya, keluarga merupakan kebutuhan manusia yang paling dasar dan menjadi pusat terpenting dari kegiatan dalam menentukan perilaku kehidupan individu di dalamnya. Jika di dalam sebuah keluarga selalu tercermin perilaku yang harmonis dan menyenangkan, maka sangat kecil kemungkinan anggota keluarga tersebut melakukan sebuah tindakan buruk yang merugikan dirinya serta orang lain.

\section{Fokalisasi}

Fokalisasi dalam teori naratif Genette berada di dalam elemen Mood. Dalam analisis mood berkaitan dengan dua hal, yaitu (1) pengaturan sedikit-banyaknya informasi yang diberikan penceritaan; dan (2) pengaturan kemunculan narator. Jika dilihat dari sudut pandang kuantitas informasi dan intensitas kemunculan narator, maka bahasan mengenai modus dapat diklasifikasikan menjadi dua hal, yakni terkait jarak atau distance dan fokalisasi atau focalization (Genette, 1980 dalam Evanda, 2017). Fokalisasi berkaitan dengan posisi pemandang dalam sebuah naratif, sedangkan untuk mengetahui siapa yang menjadi narator perlu melakukan analisis terhadap aspek tutur atau voice. Terdapat tiga jenis fokalisasi dalam naratif (Genette, 1980 dalam Lasmini, 2011), yakni fokalisasi nol, fokalisasi internal, dan fokalisasi eksternal.
Pada novel Lelaki Harimau, pengarang menggunakan pemandang orang ketiga serba tahu di mana dari perspektif inilah pikiran semua tokoh di narasikan dengan detail. Dengan menggunakan pemandang orang ketiga serba tahu, maka novel Lelaki Hariman dapat diklasifikasikan sebagai naratif berfokalisasi nol. Hal ini disebabkan karena pencerita atau pemandang dalam novel mengetahui segala hal lebih banyak dibanding dengan tokoh yang ada pada novel tersebut serta pemandang berada di luar cerita.

Narasi yang ditampilkan dalam novel Lelaki Harimau juga berisi pikiran-pikiran atau ingatan-ingatan terhadap satu tokoh dengan tokoh lainnya. Berikut merupakan salah satu kutipan di dalam novel yang menunjukkan bahwa novel ini berfokalisasi nol dengan menarasikan pikiran Mameh.

Di semesta yang remang, Mameh bisa lihat matanya yang bertambah-tambah kemilau dan tambah-tambah pijar kuning. Masih diingat kehendak Margio untuk membunuh Komar, dan kehendak itu tambah menjadijadi tanpa mesti mengatakannya. Matanya menyorot benderang, setiap lariknya seperti menancap, dan pikir Mameh, mata itu sendiri barangkali bisa bikin mati Komar bin Syueb. Namun ia juga bisa melihat penderitaannya (Kurniawan, 2016, hal. 61).

Dengan menggunakan kata ganti ia untuk menyebut Mameh, pemandang tersebut dapat dikatakan sebagai omnicient, yaitu pengamat serba tahu (Gennette, 1980, hal. 187). Selain itu, pemandang juga ingatan Mameh terhadap deskripsi tokoh Margio yang terlihat seakan-akan harimau yang berada dalam dirinya dapat dilihat oleh Mameh. Pemandang tidak hanya mengetahui pikiran Mameh, namun juga semua tokoh yang berada dalam novel. Dengan demikian, dapat dikatakan bahwa novel Lelaki Hariman merupakan narasi yang berfokalisasi nol dengan menggunakan pemandang yang serba tahu (omnicient). 


\section{Tutur (Voice)}

Dalam aspek teori naratif Genette (1980), terdapat aspek tutur atau voice yang merupakan aspek tindakan berbahasa yang dipandang berdasarkan hubungan subjek. Subjek tidak hanya merujuk pada satu tokoh yang terlibat dalam suatu peristiwa, tetapi juga merujuk pada orang yang mengisahkannya atau berpartisipasi secara pasif dalam penceritaan (Evanda, 2017). Genette membagi pembahasan mengenai tutur ke dalam lima bagian, yaitu; narrating time, narrating level, person, narrator, dan naratee. Namun, pada penelitian hanya memanfaatkan bagian narator untuk mengetahui siapa pencerita pada novel Lelaki Harimau. Pada aspek narator atau penutur, Genette membaginya menjadi dua macam: (1) Heterogenic, yaitu penceritaan dengan memosisikan narator tidak terlihat atau tidak hadir. Pada penuturan jenis ini ditandai dengan penggunaan sudut pandang orang ketiga atau omnicient di mana ketidakhadiran narator tersebut bersifat mutlak; dan (2) Homodiegetic, yakni pencerita berada di dalam penceritaan dengan tokoh sebagai pencerita. Umunya penceritaan yang menggunakan jenis ini ditandai dengan penggunaan sudut pandang orang pertama (Aswidaningrum, Chasah, \& Arimbi, 2017; Evanda, 2017).

Untuk lebih mudah mengetahui penutur atau narator dalam cerita, dapat pula diketahui melalui fokalisasi di mana pada analisis fokalisasi didapatkan bahwa pemandang menggunakan sudut pandang orang ketiga yang serba tahu. Dengan demikian, didapatkan bahwa narator dalam novel Lelaki Hariman adalah heterogenic di mana narator tidak terlihat dan bukan salah satu dari tokoh pada novel. Dengan menggunakan narator yang tidak terlihat ini, maka memudahkan pembaca mengetahui secara detail sosok-sosok pada masing-masing tokoh secara objektif.

\section{PENUTUP}

Dari analisis struktur naratif pada novel Lelaki Harimau, diketahui bahwa tata, frekuensi, fokalisasi, dan tutur saling bekerja sama dan mendukung dalam membangun adanya konflik-konflik dalam teks tersebut. Dengan mengurai konflikkonflik lain yang mendukung terjadinya konflik sentral, maka dapat dipahami bahwa secara sepintas penceritaan yang dibuka dengan pembunuhan Anwar Sadat yang dilakukan oleh Margio adalah bentuk akibat dari adanya konflik-konflik yang berasal dari keluarga Margio. Konflik kekerasan rumah tangga, kasih sayang (konflik batin), dan juga balas dendam merupakan konflik pendukung yang diketahui dengan menguraikan narasinarasi yang dimunculkan secara berulang pada teks yang disebut sebagai aspek frekuensi. Selain itu, dari analisis fokalisasi dan tutur didapatkan bahwa penutur dari novel tersebut adalah narator yang berasal dari luar teks sehingga memudahkan pembaca untuk mengetahui secara detail sosok-sosok pada tokoh secara objektif sehingga dengan mudah memahami konflik-konflik yang ada dalam teks.

Melalui analisis terhadap teks ini, maka dapat disimpulkan bahwa konflikkonflik besar berbahaya yang terjadi di luar sana, bisa jadi merupakan konflik yang dipicu oleh adanya konflik-konflik internal yang berasal dari rumah tangga atau keluarga pelaku. Sehingga melalui novel Lelaki Harimau ini, pengarang menyisipkan pesan moral di mana keluarga adalah lembaga paling dasar yang sangat diperlukan untuk mengembangkan perilaku baik terhadap masing-masing anggota. Dengan adanya kasih sayang dan kedamaian dalam keluarga, maka sedikit kemungkinan terbentuknya karakter negatif pada anggota keluarga. Pentingnya penyelesai permasalahan juga harus menjadi prioritas oleh setiap individu sehingga tidak memunculkan tumpang tindih konflik yang hadir karena konflikkonflik terdahulu tidak terselesaikan. 


\section{DAFTAR PUSTAKA}

Aswidaningrum, R., Chasanah, I. N., \& Arimbi, D. A. (2017). TumpangTindih Konflik dalam Novel Kambing dan Hujan Karya Mahfud Ikhwan. Mozaik Humaniora, 17(1), 141-156.

http://dx.doi.org/10.20473/mozaik. v17i1.6596

Bramantio. (2008). Strategi Pembacaan Novel Metafiksi Cala Ibi. Tesis. Universitas Indonesia.

Chatman, S. (1980). Story and Discourse Narrative Fiction and Film. London: Cornell University Press.

Evanda, Tiara. (2017). Kajian Naratologi Roman Reckless - Steinerses Fleisch Karya Cornelia Funke. Skripsi. Universitas Negeri Yogyakarta

Furoidah, A. (2019). Maskulinitas dalam Novel-Novel Karya Eka Kurniawan. Tesis. Universitas Airlangga.

Genette, G. (1980). Narrative Discourse: An Essay in Method. Translate by Jane E. Lewin. New York: Cornell University Press.

Hartono. (2005). Tata, Durasi, dan frekuensi dalam Novel Orang-Orang Proyek Karya Ahmad Tohari: (analisis Struktur Naratif). Litera, 4(1), 52-62.

https://doi.org/10.21831/ltr.v4i01.4 884

Kurniawan, E. (2016). Lelaki Harimau. Jakarta Pusat: PT. Gramedia Pustaka Utama.
Lasmin, Mini. (2011). Fokalisasi dan Tema dalam Novel Namok Karya Park Wan Seo. Skripsi. Universitas Indonesia.

Retnaningsih, I. (2011). Konflik Batin Tokoh Utama dalam Novel Misah Simanis Bergigi Emas Karya Pramoedya Ananta Toer: Tinjauan Psikologi Sastra. Skripsi, Universitas Muhammadiyah Surakarta.

Rokhmansyah, A. (2018). Perilaku Sosial Tokoh Utama dalam Novel Pengakuan Pariyem Karya Linus Suryadi. Diglosia, 1(1), 29-44. Diglosia: Jurnal Kajian Bahasa, Sastra, dan Pengajarannya, 1(1), 29-44. https://doi.org/10.30872/diglosia.v 1 i1.7

Sardiansa, A. (2018). Perkembangan Kejiwaan Tokoh dalam Novel Lelaki Hariman Karya Eka Kurniawan: Suatu Tinjauan Psikologi Sastra. Skripsi. Universitas Hasanuddin.

Sudjiman, P. (1990). Kamus Istilah Sastra. Jakarta: Penerbit Universitas Indonesia.

Wijayanti, C. T., Hadi, P. K., \& Furinawati, Y. (2018). Dominasi Laki-laki atas Perempuan terhadap Kehidupan Seksual dalam Novel Lelaki Harimau Karya Eka Kurniawan. Widyabastra, 52-61. http://ejournal.unipma.ac.id/index.php/wid yabastra/article/view/3368

Козак, M. (2011). The Types of Reading and Exercises for Teaching Reading. http://www.eosnova.ru/PDF/osnova_10_0_696. pdf 